\title{
A sombra de Victorine
}

\author{
Annateresa Fabris * \\ Universidade de São Paulo
}

\begin{abstract}
Resumo
Lançando mão da écfrase, Régis Descott narra em Obscura (2009) a história de um assassino obcecado com os quadros de Manet, cujo modelo foi Victorine Meurent, sobretudo Olímpia e 0 almoço na relva. Psiquiatria, pintura e fotografia entrelaçam-se numa narrativa marcada pelo enigma e pelo desvario. A criação artística é a questão central do romance, conduzido por um médico-detetive igualmente apaixonado por Manet.
\end{abstract}

\section{Palavras-chave}

Pintura; fotografia; psiquiatria; écfrase; Manet.

\section{Victorine's shadow \\ Abstract}

Making use of ekphrasis Régis Descott tells in Obscura (2009) the story of a murder obsessed with Manet's paintings whose model was Victorine Meurent, mainly Olympia and The luncheon on the grass. Psychiatry, painting and photography interweave in a story whose feature lays in enigma and folly. Artistic creation is the central subject of the novel leaded by a physician-detective equally fond of Manet.

\section{Key-words}

Painting; photography; psychiatry; ekphrasis; Manet.

\footnotetext{
* Professora titular aposentada da ECA/USP. Autora de diversos livros, entre os quais O futurismo paulista (1994), Fragmentos urbanos: representações culturais (2000), Identidades virtuais: uma leitura do retrato fotográfico (2004), Fotografia e arredores (2009), O desafio do olhar: fotografia e artes visuais no período das vanguardas históricas (v. 1, 2011; v. 2, 2013) e A fotografia e a crise da modernidade (2015). 
Modelo do ateliê de Thomas Couture (1860), no qual Édouard Manet havia estudado entre 1850 e 1856, Victorine Meurent era apelidada "O camarão" pela pequena estatura e pela cabeleira ruiva. É possível que a jovem tenha encontrado Manet em 1862, já que este a representa em três quadros pintados naquele ano: Retrato de Victorine Meurent, Senhorita V... em traje de espada e Cantora de rua. A recepção dessas primeiras obras, em que 0 pintor começa a "inventar" Victorine, transformando-a de modelo em mulher (Darragon et al., 1998: 79), não é das melhores. Senhorita V... em traje de espada é criticado por Théophile Thoré pelo tratamento igual dado ao corpo, à cabeça e aos panejamentos (Darragon et al., 1998: 59). Cantora de rua, por sua vez, perturba Paul Mantz por uma singularidade: "as sobrancelhas renunciam à sua posição horizontal para colocar-se verticalmente ao longo do nariz como duas vírgulas de sombra. [...] 0 efeito é insosso, duro e sinistro" (apud Lethève, 1959: 23). Uma exceção nesse panorama é Émile Zola (1970: 106), o qual, num longo artigo dedicado a Manet (1867), avalia positivamente a gama cromática de Cantora de rua, que remete a uma análise da natureza, feita "com uma simplicidade e uma exatidão extremas", à busca da verdade e ao "trabalho consciencioso de um homem que quer, antes de tudo, dizer francamente o que vê".

Meurent, que foi também modelo de Edgar Degas, Alfred Stevens, Norbert Goeunette e Henri de Toulouse-Lautrec, atraiu a atenção de diversos escritores, que a transformaram em personagem ou protagonista de relatos autobiográficos (George Moore, Memoirs of My Dead Life, 1906), de biografias ficcionais (Eunice Lipton, Alias Olympia: a Woman's Search for Manet's Notorious Model and Her Own Desire, 1992) e de romances (Debra Finerman, Mademoiselle Victorine: a Novel, 2007; V. R. Main, A Woman With No Clothes On, 2008; Christopher Moore, Sacré Bleu: a Comedy d'Art, 2012). A essas obras pode ser acrescentado o romance policial Obscura (2009), de Régis Descott, em que Victorine paira como uma sombra, ao ser evocada por algumas obras das quais foi modelo: 0 almoço na relva (1863), Olímpia (1863) e Mulher com papagaio (1866). Uma única vez a jovem aparece como ela mesma por meio da lembrança de Gabriel Corbel, o qual 
relata ao filho a visita que esta fizera a sua loja de tintas, quando provavelmente já estava se dedicando à pintura ${ }^{1}$. A lembrança do velho comerciante põe em cena outra obra para a qual ela posou - $A$ ferrovia (1872) -, acompanhada de um comentário instigante sobre a relação de Manet com sua modelo preferida2: em cada obra, este a representava com uma cabeça diferente, sem que isso impedisse seu reconhecimento (Descott, 2010: 255).

Não é exagerado falar de uma Victorine-sombra no caso do romance de Descott, já que Pauline Maupin ${ }^{3}$, Henriette Ménard, Marceline Ferrault (Obscura) e Sibylle Auclair, raptadas para participar de singulares tableaux vivants que reconstituíam 0 almoço na relva e Olímpia, se pareciam, de algum modo, com ela. Antes de adentrar a questão dos tableaux vivants, parece ser necessário compreender como Manet, que fora ridicularizado pela crítica e pelo público e que só tivera poucos defensores, entre os quais Zola e Stéphane Mallarmé, se torna objeto de uma admiração misturada com inveja por parte do reencenador de suas composições. Como lembra Zola (1970: 359), o qual havia prognosticado em 1867 que Manet tinha um lugar assegurado no Museu do Louvre, o artista conhecera uma "súbita apoteose" logo depois de sua morte, ocorrida em 30 de abril de 1883. Na realidade, o pintor conseguira, em diversas ocasiões (1873, 1876 e 1882), apossar-se da animosidade da imprensa e aproveitá-la de maneira positiva, respondendo a suas críticas com argumentos tomados dela mesma. Sem ser um manipulador, consegue dominar a aura de escândalo que cerca suas obras (Darragon et al., 1998: 101), sendo finalmente premiado com a segunda medalha do Salão de 1881 por 0 senhor Pertuiset, caçador de leões $(1881)^{4}$. No ano seguinte, recebe a Legião de Honra, confirmando

\footnotetext{
1 É provável que Meurent tenha frequentado o ateliê feminino de Couture por volta de 1860. Na década de 1870, começou a praticar a pintura, tendo participado de seis Salões, entre os quais os de 1876, 1885 e 1904. Em 1879, uma de suas obras foi recebida pela Escola de Belas-Artes. Foi membro da Sociedade dos Artistas Franceses (1906). Um de seus quadros, Domingo de ramos (década de 1880), recuperado em 2004, está exposto atualmente no Museu Municipal de Arte e História de Colombes.

2 Duas outras modelos constantes de Manet são Berthe Morisot e Méry Laurent.

${ }^{3} \mathrm{~A}$ jovem não chega a ser utilizada como modelo. Após ter mordido o nariz do cúmplice do assassino, tinha sido espancada até tornar-se inutilizável e seu corpo fora jogado no Sena (Descott, 2010: 215-216).

${ }^{4} \mathrm{O}$ quadro faz parte do acervo do Museu de Arte de São Paulo Assis Chateaubriand.
} 
seu ingresso na categoria dos artistas consagrados. Em 1884, dois acontecimentos consolidam sua reputação: a exposição organizada no "santuário da tradição" (Zola, 1970: 359), a Escola de Belas-Artes, e a venda das obras de seu ateliê, entre as quais Olímpia, arrematada pelo cunhado para que permanecesse com a família 5 .

É, portanto, um artista famoso o que atrai a atenção de um amador de arte bem particular, já que a ação de Obscura tem início em 17 de abril de 1885, quando duas faxineiras se deparam com uma cena macabra numa casa de campo situada nos arredores de Aix-en-Provence. 0 doutor Jean Corbel, protagonista do romance, toma conhecimento do fato por meio de uma carta do amigo Marcel Terrasse, incumbido pela polícia de constatar um falecimento na casa. O que havia assustado as faxineiras era uma cena sui generis: o cadáver de uma mulher sentada no chão, com uma perna dobrada, o cotovelo preso ao joelho por uma pequena corda, o queixo repousando na mão. Inteiramente nu, o cadáver era ladeado por dois manequins de madeira vestidos com roupas masculinas. No fundo da cena havia um telão sobre o qual estava pintada uma paisagem campestre com um charco e uma mulher de camisola banhando-se nele. 0 cadáver de Clémence Abello, roubado do cemitério de Aix-en-Provence, estava em avançado estado de decomposição, rodeado de moscas de diferentes espécies (Descott, 2010: 65-67).

O doutor Corbel, que ouvira falar de uma reconstituição de Olímpia feita num bordel a pedido de um cliente, da qual haviam participado duas prostitutas (Obscura e Yvette) e um gato pintado de preto, depara-se pessoalmente com outro tableau vivant de 0 almoço na relva, numa casa abandonada de Auteuil. A reconstituição, dessa vez, era mais perfeita que a da Provença. Dois manequins com bonés estavam sentados no chão. Vestido com uma calça cinza, um casaco preto, uma camisa branca e uma

\footnotetext{
5 Em 1890, Olímpia é doada ao Museu do Luxemburgo graças a uma subscrição nacional, da qual participam Claude Monet, Degas, Pierre-Auguste Renoir, Auguste Rodin, Joris-Karl Huysmans, Gustave Geoffroy, Mallarmé, Jean Béraud e Carolus-Duran, entre outros. Em 1907, a obra é transferida para o Louvre por iniciativa do primeiro-ministro Georges Clemenceau, de quem Manet pintara dois retratos em 1879-1880. 
gravata laranja, o primeiro levava uma bengala na mão esquerda. Com a perna esquerda esticada no chão, o busto levantado, estava apoiado no antebraço esquerdo, enquanto o braço direito parecia apontar para algo ausente por meio do indicador. $\mathrm{O}$ segundo manequim trajava uma calça $\mathrm{e}$ uma camisa brancas e uma gravata e um casaco pretos. Apoiava-se na mão direita, enquanto a esquerda repousava no joelho direito. Com exceção das barbas postiças costuradas, "seus rostos de tecido branco eram tão uniformes quanto cascas de ovos". No primeiro plano, via-se um vestido azul sobre o qual repousava um chapéu de palha com uma fita azul escuro. Havia também uma cesta de frutas meio tombada, da qual saíam algumas peras e um punhado de cerejas. Uma grande tela em trompe-l'oeil, como as utilizadas nos ateliês fotográficos, mostrava uma cena campestre: algumas árvores de folhagem escura, um barco e uma banhista de cabelos morenos vestida com uma camisola, "pintada grosseiramente, como se 0 pintor fosse destituído de todo talento". Ao conjunto faltava o cadáver, retirado pela polícia. Sua ausência produzia um efeito "ainda pior": o tableau vivant dava "uma impressão particularmente sinistra" com sua "encenação macabra" e os dois manequins sem olhos, "imobilizados em poses grotescas" (Descott, 2010: 161-162).

A descrição minuciosa feita por Descott convoca duas questões: o uso de um artifício retórico como a écfrase e a relação da narrativa com as críticas feitas aos quadros de Manet. Gênero cultivado desde o fim da antiguidade, a écfrase é uma maneira de descrever bem detalhada que, graças à força das palavras, evoca a imagem mental do objeto descrito. 0 que Descott pratica não é a écfrase tradicional, e sim um gênero que Alexandra Vranceanu (2013: s.p.) define "romance ecfrástico contemporâneo". Tratase de uma narrativa inspirada em obras de arte célebres, que atraem 0 autor por sua capacidade de engendrar um enredo. Baseado numa extensa pesquisa de fontes e no uso da obra como documento histórico complexo, profundamente transformado pelo intertexto que o cerca, esse tipo de narrativa apresenta também semelhanças com o romance de artista, surgido na França no século XIX, cujos principais exemplos são $A$ obra- 
prima ignorada (1831), de Honoré de Balzac, Manette Salomon (1867), de Edmond e Jules de Goncourt, e A obra (1886), de Zola.

Vranceanu (2013: s.p.) aventa a hipótese de que Descott se inspirou nas críticas feitas a Manet por ocasião da exposição de 0 almoço na relva (1863) e Olímpia (1865), fazendo deles rebus, enigmas visuais, que atraem o olhar e pedem uma solução. A recepção do primeiro quadro, apresentado no Salão dos Recusados, foi, de fato, negativa, levando a crítica a falar em "rebus" (Théodore Pelloquet) e em "logogrifo pouco decoroso" (Louis Etienne). Mesmo Thoré, que tem simpatia pelo artista, não deixa de manifestar o próprio espanto. 0 crítico fala em "provocação ao público", em "gosto bem arriscado", em nu não idealizado, em feiura da figura masculina, ao mesmo tempo em que ressalta as qualidades cromáticas e luminosas da paisagem e "trechos bem reais de modelado no torso da mulher". 0 veredicto final é a prova cabal da perplexidade do crítico, que não consegue imaginar o que levou "um artista tão inteligente e distinto" a conceber "uma composição tão absurda" (apud Lethève, 1959: 24). Exposta no Salão de 1865, Olímpia é igualmente alvo de ataques virulentos contra um artista que ousava apresentar "desafios", "zombarias ou paródias". Nada escapa da fúria dos críticos: a mão em forma de sapo, que causa hilaridade e risos nervosos, o desenho ruim, o cromatismo quase sempre desagradável (Ernest Chesneau); a vontade de atrair os olhares a todo custo (Théophile Gauthier); a "odalisca de ventre amarelo, ignóbil modelo apanhado sabe-se lá onde" (Jules Claretie). A crítica mais áspera parece ser a de Félix Deriège, que ataca, sem meias medidas, a "feiura acabada" da cortesã, a tal ponto estropiada pelo pintor que seria impossível imaginá-la mexendo braços e pernas; seu rosto estúpido; o gato "arrepiado que parece vir do sabá de Callot6"; a "algazarra espantosa" do cromatismo; a "confusão de

${ }^{6}$ Gravador e desenhista do século XVII, Jacques Callot distingue-se pela nitidez do traço, pela sensação de vida e movimento e pela propensão ao grotesco, ao burlesco, ao extravagante e ao quimérico. Sua produção abarca temas religiosos, cenas históricas, retratos, festas e feiras, personagens pitorescos e paisagens. Entre suas obras destacamse: Os caprichos (1617), A feira de Impruneta (1620), Os balli de Sfessania (1620-1622), Os gobbi (1620-1622), Os mendigos (1622), O sítio de Breda (1628), As pequenas misérias da guerra (1633) e As grandes misérias da guerra (1633). A série dos Balli de Sfessania inspirou o conto Prinzessin Brambilla. Ein Capriccio nach Jakob Callot [Princesa Brambilla. Um capricho à maneira de Jacques Callot, 1820], de E.T.A. Hoffmann.

Revista do Programa de Pós-graduação em Arte da UnB V.15, $n^{0} 1$ /janeiro-junho de 2016 
cores disparatadas, de formas impossíveis", que atrai o olhar e estupefica (apud Lethève, 1959: 31-33)7.

A observação de Deriège a respeito da "pele cadavérica" de Olímpia pode servir de elo com a fixação do misterioso personagem de Descott por cadáveres. Depois de ter visto o tableau vivant de Auteuil, o doutor Corbel se pergunta como uma obra de arte poderia estar na origem de um crime; que espírito perturbado seria capaz de matar para reproduzir um quadro nos mínimos detalhes; que tipo de crueldade levava o assassino a instalar a vítima diante do aquecedor, "instrumento de tortura e de morte". Tendo chegado à conclusão de que a morte de Henriette Ménard apontava para "um assassino alheio às paixões correntes e à normalidade", o médico traça um paralelo entre Manet e seu êmulo. Tratava-se de duas faces de uma mesma moeda, "o gênio luminoso de um lado, seu reflexo escuro de outro, o sol negro". Que objetivo perseguia o assassino? Incapaz de "igualar o gênio de Manet, o matador se dedicaria a convertê-lo em derrisão?". Poria em prática a própria "monomania homicida para transformá-la numa obra, a obra negra?". Com a ajuda do doutor Gérard Roch, que trabalhava na clínica do psiquiatra Émile Blanche, Corbel é confrontado com a hipótese de que 0 assassino deveria ser buscado na alta sociedade, já que se tratava de alguém muito inteligente e mergulhado numa paixão artificial (Descott, 2010: 165, 178, 202-203).

Essa hipótese, que será confirmada pelo desenrolar da narrativa, permite estabelecer outro elo entre Manet e o assassino. Como ele, o artista provinha da alta sociedade, tendo impregnado as próprias obras de qualidades que remetiam a uma personalidade segura e distinta, a uma elegância feita de indolência e de uma reserva irônica. Não precisando fazer da arte um ganha-pão, não buscava a aprovação do público, embora não o desprezasse. Mais próximo do amador esclarecido que do

\footnotetext{
7 Descott (2010: 49) evoca a recepção de Olímpia através da lembrança do doutor Corbel. O quadro havia sido atacado com epítetos injuriosos: "odalisca de ventre amarelo", "macaca simulando a pose e o movimento do braço da Vênus de Ticiano", "Vênus hotentote exposta nua como um cadáver nas lajes do necrotério". Além disso, a mão "impudicamente crispada" tinha suscitado pensamentos obscenos. 
profissional interessado em fazer carreira, sentia-se livre para explorar novas ideias e realizar experiências, procurando os próprios modelos na vida moderna e não na história e na literatura, como fazia a grande maioria dos artistas contemporâneos. Não deixava de dialogar com o passado, visto de maneira irônica. Gustave Courbet serve-Ihe de modelo na adoção de duas estratégias fundamentais: tomar o próprio universo como tema, revelando assim a própria posição social e os próprios pontos de vista artísticos; praticar uma provocação deliberada por meio de uma controvérsia moral e estética. 0 almoço na relva e Olímpia suscitam indignação por mostrarem a modelo despida e não idealizada como num nu acadêmico. Intitulado originalmente $\mathrm{O}$ banho, o primeiro quadro adquire um significado ulterior com a renomeação de 1867: alude à moda dos passeios nos arredores de Paris e à liberalização dos costumes, sobretudo no caso das mulheres. Visto nessa perspectiva, o quadro demonstra ser uma paródia dessa moda, na qual poucos enxergaram uma "modernização" sarcástica de dois protótipos clássicos: a gravura O julgamento de Páris (c. 1517-1520), de Marcantonio Raimondi, e a tela O concerto campestre (c. 1510), de Giorgione ${ }^{8}$. Pintada no mesmo período, Olímpia suscita um escândalo ainda maior. Representa uma mulher nua, que não disfarça a própria profissão, cobrindo com a mão e enfatizando ao mesmo tempo 0 objeto do próprio negócio. Inspirada também na tradição, a obra é uma interpretação irônica da Vênus de Urbino (1538), de Ticiano: a deusa é substituída por um "ser frio e dominador"; um gato, símbolo de liberdade, toma o lugar do cachorro, emblema da fidelidade. Mais uma vez, o pintor lida com um tema contemporâneo: a prostituição, difusa em Paris desde a década de 1830 em virtude do êxodo rural. Celebrada na literatura - $A$ dama das camélias (1852, Alexandre Dumas Filho) e Germinie Lacerteux (1865, Edmond e Jules de Goncourt) - e na ópera La traviata (1853, Giuseppe Verdi), a figura da prostituta encarna para Manet a

\footnotetext{
8 No artigo dedicado a Manet em 1867, Zola (1970: 107-108) põe em xeque a indignação do público com a representação de uma mulher nua entre dois homens vestidos. Lembra, para tanto, que havia no Louvre mais de cinquenta quadros caracterizados pela mistura de figuras nuas e vestidas. Ao concentrar-se tão somente no tema, 0 público detectava "uma intenção obscena e turbulenta" no quadro, sem perceber que o artista "havia simplesmente procurado conseguir oposições vivas e massas francas".
} 
comercialização das relações humanas no mundo moderno. De acordo com essa percepção, o artista evita o tema da sedução, apresentando uma mulher de carne "quase borrachuda", que se oferece prosaicamente "como uma lula no balcão de um peixeiro" (Rubin, 2008: 51-53, 59-62, 65-68) ${ }^{9}$.

Filho de um rico industrial e herdeiro de uma fortuna considerável, Lucien Favre ${ }^{10}, 0$ assassino, é um pintor fracassado que se converte em fotógrafo. Zombado pelo professor por ter executado um retrato equestre da mãe, que se distinguia pela presença de um cavalo de "proporções bizarras", o jovem Favre dedica-se à fotografia, mas não perde de vista a pintura; para assegurar a ressonância do próprio trabalho decide basear-se no "aspecto escandaloso de certas telas". Manet torna-se seu alvo não apenas pela aura de escândalo que o cercava, mas também, e talvez sobretudo, por ter pintado um retrato de Nélie Favre, sua mãe, em 1873. A própria senhora Favre, internada na clínica do doutor Blanche, reconhece que o filho, enciumado pela atenção dada ao pintor, visto por ela como um talento, resolve procurar um caminho próprio, executando 0 almoço na relva com um cadáver. O complexo de Édipo, aliado à impotência e a um temperamento mórbido e violento, está na base da busca de "construções mentais" preparadas de antemão para não escapar de seu controle. A relação com a câmara fotográfica não é apenas técnica. 0 pano preto que o recobre durante a tomada dá-lhe a ilusão de uma vida intrauterina, de um contato íntimo e exclusivo com a mãe. Concebendo a criação como uma "soma de esforços e de sofrimentos", resolve dedicar-se a um gênero singular de fotografia, sem medir riscos e despesas. $O$ verdadeiro objetivo de seu trabalho é revelado numa longa reflexão a respeito da recriação de

\footnotetext{
9 Para Michel Leiris (2006: 67, 150), Olímpia é uma garota de seu tempo, como mostram o buquê trazido pela "amável negra de roupa clara" e os enfeites usados - a fina fita preta no pescoço, o grande nó cor de rosa no cabelo, os brincos, a pulseira e os chinelos -, que a subtraem da dimensão do "nu integral", tornando-a mais excitante. A ocultação do sexo parece encontrar um substituto em três elementos do quadro: 0 aspecto luxuriante do buquê de flores, a cor preta do felino e o ornamento barato do cabelo que evoca o órgão não visível. Olímpia é um bibelô gracioso, uma garota-boneca tão branca e tão fria quanto a criatura por quem se apaixona o herói de 0 homem da areia (1815), que revela ser um autômato dotado de um alto grau de ilusão.

10 Favre corresponde ao perfil do alienado mental traçado por Philippe Pinel. Filho único de uma mãe fraca e indulgente, não mede esforços para satisfazer as próprias vontades. Desprovido de compaixão, representa socialmente o papel de benfeitor, participando do financiamento do Hospital Saint-Louis e projetando a construção de um orfanato (Descott, 2010: 361-363).
} 
outra obra de Manet, O tocador de pífano (1866). Seu processo de criação não se limitava a uma única tomada, feita algumas horas depois da morte dos modelos por asfixia gasosa. 0 que ele pretendia era reproduzir 0 trabalho do pintor às avessas, "partindo do quadro acabado para realizar em seguida uma série de esboços com traços cada vez menos precisos". O que sua câmara registrava eram os vários estágios de decomposição do modelo:

Desde a primeira imagem, a fisionomia do garoto tinha se modificado profundamente. $\mathrm{O}$ aspecto vivo que tinha conseguido preservar algumas horas depois da morte tinha cedido lugar rapidamente a algo indefinido, antes que 0 desenho do rosto se desarranjasse, o nariz se achatasse, os lábios se inchassem e os olhos vazios de todo brilho intumescessem, com o conjunto adquirindo cores que suas imagens não podiam traduzir (Descott, 2010: 271-275, 374, 384, 386).

Sua rivalidade com Manet é explicitamente declarada nessa longa reflexão. Um garoto vestido com um uniforme "não podia exercer a mesma atração do corpo de uma mulher inteiramente despida". Um pensamento, no entanto, o reconforta. As lendas sobre o quadro diziam que o pintor havia recorrido a sua modelo-fetiche, Victorine Meurent, já que o jovem músico não conseguia manter a pose ${ }^{11}$. Tomada a última imagem - o último esboço que na pintura seria o primeiro -, Favre dá-se conta da realidade de sua criação: uma encenação "tão sinistra quanto macabra", na qual o pequeno músico, que empesteava o ar com "uma intensidade apenas suportável", não passava de um cadáver, quando dissociado do prisma das lentes. Uma reflexão posterior prova que esse tipo de inconveniente não impede que 0 fotógrafo tenha em alta consideração o aspecto inovador de sua criação. Arte nascida com a Revolução industrial, "sem cor, mecânica, química, instantânea em sua realização", a fotografia repousava "numa concepção longamente amadurecida". Arte "da duplicação" e não de obras únicas, a fotografia necessitava de uma infinidade de recursos, o que a tornava "infinitamente superior ao que a tinha precedido. Não se tratava mais de

\footnotetext{
${ }_{11}$ Partindo de uma afirmação de Paul Jamot, que havia enxergado no rosto do garoto as feições de Meurent, Lionello Venturi (1970: 156) afirma que essa hipótese estava de acordo com o estilo de Manet. Éric Darragon (1998: 60) rechaça essa ideia, mesmo evocando os vários disfarces com que a modelo foi representada pelo pintor. O modelo do quadro vinha do quartel da Pépinière, sendo possível que Léon Koella, filho da esposa de Manet, Suzanne Leenhoff, tenha igualmente posado. 
habilidade manual, de capacidade de reproduzir fielmente este ou aquele tema, mas de uma obra de puro espírito". Seu método de trabalho com cadáveres tinha outra vantagem: os modelos "não estavam demasiado presentes, não o incomodavam com seu cheiro ou seus olhares, às vezes muito insistentes". Sua passagem pelo ateliê, concebido como um aviário, só era atestada por um enxame de moscas que se chocavam regularmente contra os vidros, caindo mortas no assoalho (Descott, 2010: 276-277, 414).

O topos da rivalidade entre artistas, que perpassa a relação de Favre com Manet, alcança o apogeu quando aquele se prepara para a tomada de Olímpia, para a qual havia sido necessário matar Obscura e Yvette, a martinicana, e conseguir um gato preto de olhos amarelos num taxidermista. O pintor e seus quadros deviam ser considerados "um degrau, uma base na qual se inspirava para soltar sua obra, assim como Manet que, para Olímpia, tinha se inspirado na Vênus de Urbino, de Ticiano, e na Maja desnuda, de Goya". Desse modo, ele se inscrevia nessa tradição, "levando ainda mais longe a audácia que tinha rendido tantas críticas a Manet. Logo não necessitaria mais de tais suportes ou fontes de inspiração. Em pouco tempo começaria o próprio caminho que ninguém, antes dele, tinha tomado e, muito menos, desbravado" (Descott, 2010: 416). Todos os motivos da rivalidade entre artistas estão presentes nessa digressão, dando a ver 0 conhecimento de Descott a respeito desse item quase inescapável de toda biografia artística. A pretensão de Favre de ser superior não só a Manet, mas a todos os pintores que o haviam antecedido, ecoa a disputa entre Zêuxis e Parrásio em torno do poder de ilusão do próprio trabalho, ou a rivalidade entre Apeles e Protógenes, alicerçada na capacidade de desenhar a linha mais fina. Outro aspecto a ser destacado é o tratamento que ele dá aos quadros de Manet: o uso de cadáveres e manequins poderia ser interpretado como uma crítica ao trabalho do rival, como uma observação depreciativa sobre sua criação, em que pese o cuidado da reconstituição. Um terceiro elemento diz respeito ao conflito de gerações, patente na vontade de realizar uma obra absolutamente inédita (Kris; Kurz, 1988: 106-108). 
Favre não percebe que não poderia contrapor à "celebração da vida" das obras de Manet sua "caricatura malsã" enraizada na morte (Descott, 2010: 472), assim como não leva em conta que a prática do tableau vivant e da emulação fotográfica da pintura não era exclusiva de seu modus operandi. Afinal, desde a década de 1850, havia fotógrafos que se dedicavam a "ilustrar a poesia e o sentimento", enveredando pelo caminho da alegoria, da imitação da pintura holandesa, inglesa, acadêmica e contemporânea, da composição de cenas de gênero, de naturezas-mortas, ou buscando suas fontes de inspiração em poemas e figuras literárias, lendárias, mitológicas e heroicas. A própria defesa da superioridade da imagem técnica, exceto no momento em que a define "arte da duplicação", não deixa de ser uma retomada do debate que se instaura na segunda metade do século XIX, quando os fotógrafos recorrem a temas "elevados" e imaginativos para negar que ela não passava de uma simples reprodução da realidade. Não faltam nesse debate equiparações entre fotografia e pintura em termos de concepção e composição: as duas operações usavam os mesmos procedimentos mentais, um igual tratamento artístico, uma ideia de elaboração semelhante, já que lançavam mão de leis e conceitos formais derivados da tradição (Fabris, 2011: 17-29).

Se, no âmbito dessa tradição, a elaboração de tableaux vivants não constitui uma novidade, o mesmo pode ser dito a respeito da presença de cadáveres em fotografias. Nos albores da imagem técnica, Hippolyte Bayard testa seu poder ilusionista com Autorretrato como afogado (1840), em que se representa seminu e apoiado contra uma parede, como se estivesse morto. Foi a maneira encontrada para protestar contra 0 desinteresse do governo francês por seu invento - o positivo direto sobre papel -, elogiado pela Academia de Belas-Artes, que o considerava artisticamente superior ao daguerreotipo. Em termos sociais, era grande 0 interesse do público pela exposição de fotos de vítimas de assassinatos ou de outros episódios violentos, feita, não raro, nas sedes de jornais. Além disso, a voga da fotografia pós-morte permitia que os parentes guardassem 
uma lembrança do defunto, motivo pelo qual a imagem, pelo menos nos primeiros tempos, deveria proporcionar uma ilusão de vida. A tomada mais frequente era um primeiro plano do rosto repousando num travesseiro, como se estivesse dormindo. No caso de bebês e crianças pequenas não era incomum a composição de uma cena familiar, com o cadáver nos braços da mãe, do pai ou de um irmão. Favre não desconhecia essa última prática, já que possuía um daguerreotipo do pai no leito de morte, desfigurado pelo suicídio, no qual parecia buscar "conforto ou aprovação" (Descott, 2010: 373, 376-377). Esse culto mórbido estaria na base da determinação de trabalhar na contramão do retrato pós-morte, sujeitando os quadros de Manet a diferentes estágios de decomposição?

Ao manifestar o desejo de fazer parte da grande tradição artística, o fotógrafo não expressa apenas o desejo frustrado de ser um pintor reconhecido; demonstra também não ter compreendido o modo como Manet se relacionava com os modelos do passado. Ao contrário do quadro de Giorgione, no qual as figuras só se relacionavam visualmente entre si, 0 almoço na relva distingue-se pelo olhar que Victorine dirige diretamente ao espectador, envolvendo-o numa representação avessa a toda narrativa e a toda simbolização. A modelo do pintor é uma mulher contemporânea e não uma musa intemporal, que alude à força inspiradora da natureza sobre a arte. O mesmo acontece com Olímpia, representação de uma cortesã, que não disfarça seu comércio sob uma idealização clássica, como na tela de Ticiano. Com suas paródias da arte tradicional, Manet quer chamar a atenção para a clivagem existente entre realidade e convenção e sobre si mesmo como agente dessa revelação (Rubin, 2008: 63-65). o que faz Favre? Trivializa a paródia sem entender adequadamente seu alcance e a afirmação de independência contida nela. Os modelos mortos de que se serve não podem encarar o observador e envolvê-lo diretamente na cena. Os manequins masculinos, destituídos de olhos, nada mais fazem do que aludir à sua identificação com um desejo pervertido (Chevalier; Gheerbrant, 1991: 587). Não há em suas composições a autonomia alcançada por 
Manet, que faz do motivo um simples pretexto para a criação de imagens dotadas de uma existência puramente estética (Venturi, 1970: 150).

O artigo "Os impressionistas e Édouard Manet" (1876), de Mallarmé, permite aventar outra hipótese para o interesse de Favre pelo pintor. É possível pensar que ele tenha percebido as qualidades fotográficas da obra do antecessor, indo além da constatação de que este se serviu de fotografias para realizar um quadro como $A$ execução de Maximiliano (1868-1869) e alguns retratos (Edgar Allan Poe, 1856; Charles Baudelaire, 1865; Méry Laurent, 1881-1882, por exemplo), caracterizados pelo predomínio de zonas muito escuras e muito luminosas, em cujo interior são perceptíveis apenas mínimas modulações tonais, e pela opção por fisionomias construídas com matizes delicados e evanescentes (Scharf 1979: 62-63). Outro uso é assinalado por Éric Alliez (2007: 193), que lembra que o pintor usava imagens fotográficas dos próprios quadros, retocadas com aquarela e guache, para produzir pequenas aquarelas. Embora não fale em fotografia, várias observações de Mallarmé (2005: 308, 310-311, 313-319) remetem a ela: ausência de hierarquia entre os elementos da composição ("dando à primeira vista a impressão habitual do motivo que as fez nascer"); ruptura do olho, obrigado a reaprender a partir do confronto com o que está diante dele, com a memória e transformação da mão num "órgão de abstração impessoal, dirigido somente pela vontade, esquecido de toda destreza anterior"; busca do verdadeiro no espetáculo da vida moderna; interesse pela luz natural ("o espaço com apenas a transparência do ar"); reprodução da natureza tal como ela se mostra a "olhos justos e puros"; impressão de casualidade dada pela maneira de cortar o quadro (cena abarcada de um golpe "no enquadramento de mãos"); impessoalidade ("ausência de toda intrusão do eu na interpretação [...] da natureza"); instantaneidade e possibilidade de multiplicação das composições. A esses aspectos pode ser acrescentado outro: seu tratamento plano da superfície da tela, no qual Clement Greenberg (1997: 102) localiza o começo da pintura moderna, guarda relações não desprezíveis com várias fotografias contemporâneas. 
Antes de Favre ser desmascarado, o doutor Corbel havia chegado à conclusão de que 0 assassino deveria ser um fotógrafo. Ao deparar-se com a vitrine de um ateliê fotográfico, deixa que os olhos percorram seu conteúdo: câmaras escuras e retratos engastados em molduras de baquelita preta. Intrigado com as imagens de pessoas imobilizadas em "poses rijas e compassadas, homens engravatados, mulheres com golas de renda que mantinham o queixo elevado", compreende finalmente o que atraíra sua atenção: o letreiro Camera Obscura. Compreende então o que o doutor Blanche, consultado por ele e Roch, dissera a respeito da necessidade de deixar uma marca, sentida por todo assassino e por todo artista. Compreende, sobretudo, a natureza do que havia chamado sua atenção na casa de Auteuil. As marcas triangulares no tapete, desprezadas pela polícia, provinham do tripé de uma câmara escura, "camera obscura em latim". Após concluir que se tratava de um fotógrafo letrado, Corbel evoca outro dado: na segunda carta de Terrasse havia referência a postigos abertos na casa de campo provençal, o que indicava que o autor do tableau vivant precisava de luz diurna para suas fotografias. Essa conclusão levao a concordar, mais uma vez, com o diagnóstico de Blanche, que apontava para um monomaníaco possuído por um desejo de criação artística e movido "por imitação e por orgulho", para quem o homicídio era um meio, não um fim. Num crescendo de evocações vêm-lhe à mente as figuras de Obscura e de seu estranho cliente, que a havia feito posar como Olímpia no bordel e que the dera o apelido (Descott, 2010: 162-163, 238-240).

O que o médico não sabe naquele momento e que perceberá mais tarde é que o misterioso cliente e o protetor de Obscura são a mesma pessoa. Ao visitá-la em seu apartamento para interrogá-la sobre o cliente, dar-se-á conta de que a jovem evocava outro quadro de Manet, A mulher com papagaio (1866). Tudo remetia a ele: o longo penteador cor de rosa pálido, vestido por Obscura, cujos punhos e cuja gola aberta eram ornados com uma fina renda branca; os cabelos presos numa fita azul; um papagaio 
cinzento preso a um poleiro por uma pequena corrente ${ }^{12}$. Obscura teria consciência de ter sido transformada em modelo em sua própria casa? Que papel desempenhava na trama? Seria cúmplice do assassino? (Descott, 2010: 298, 387).

O envolvimento de Corbel na caça ao assassino, mesmo antes de sua companheira Sibylle"13 ser raptada para servir de "modelo suplementar, à guisa de esboço, antes da obra-prima" (Descott, 2010: 215), tem uma explicação. Assim como Favre, ele também admirava Manet, tanto que havia feito uma cópia de Olímpia, tendo Sibylle como modelo. Pendurada na parede do consultório, onde fora notada por Obscura, a pequena cópia parecia-lhe bem sucedida, sobretudo no tratamento do rosto, "mistura de arrogância e de melancolia, que aflorava sob esse olhar. [...] Sua interpretação do quadro de Manet revelava outra Sibylle sobre a qual desabrochava uma sombra, e nesse sentido mais próxima de Olímpia. Os cabelos também tinham saído bem, com seu reflexo acaju e a flor laranja pendurada na orelha esquerda". Os lençóis e os travesseiros, assim como a martinicana com o buquê, não se distinguiam pela fatura, dando a impressão de que ele tinha concentrado sua atenção na mulher, "no movimento dos braços, no porte da cabeça, em sua languidez" (Descott, 2010: 94).

O romance não oferece uma descrição física de Nélie Favre; Descott (2010: 293, 296, 351) limita-se a apresentá-la como uma pessoa de aparência

120 quadro de Manet tem outros detalhes não citados na descrição de Descott: a jovem está cheirando um pequeno buquê de violetas; traz no pescoço uma corrente fina, na qual está preso um monóculo; aos pés do poleiro do papagaio há um limão meio bicado. Para alguns autores, o buquê de violetas e o monóculo aludiriam a uma presença masculina, reforçada pela figura do papagaio, referência explícita ao órgão sexual (Manet - Kerdonis, s.d.). Essa última hipótese parece ser corroborada no romance pela cena do jogo erótico entre Obscura e o animal, durante a qual o protetor começa a sentir "agradáveis comichões" na ponta do pênis, enquanto a jovem finge ignorar sua presença e o efeito provocado sobre ele pelo espetáculo (Descott, 2010: 132).

${ }^{13}$ Atriz e modelo eventual, tinha sido descoberta pelo doutor Roch no Hospital da Salpêtrière, onde imitava as diferentes facetas da histeria para um público de estudantes, médicos e internos. Encenando as transformações desejadas pelo doutor Jean-Martin Charcot, imprimia a seu rosto esgares expressivos e mantinha a pose durante os comentários do médico. Seu corpo adotava posturas bem eloquentes, "imitando com uma eficácia surpreendente 0 furor, a tristeza, a raiva, a excitação, a alegria, a hebetude". O que mais fascinava o doutor Corbel, que 0 amigo pusera a par da descoberta, eram as metamorfoses do rosto deslumbrante, "que, em poucos segundos, se transformava numa máscara de pesadelo" (Descott, 2010: 34-35). 
respeitável, dotada de belos olhos pretos, como uma das mulheres mais belas e mais ricas de Paris. Apesar dessa descrição sucinta, surge uma pergunta na mente do leitor: Nélie Favre não teria alguma semelhança com Victorine Meurent, moça de traços delicados e talhe esbelto, a julgar por um retrato fotográfico de 1864 , quando tinha vinte anos? O relacionamento de Favre com a figura materna, o ciúme que sentia dela, manifestado não apenas na rivalidade com Manet, mas também no assassinato do noivo pouco antes da celebração do segundo casamento, poderiam estar na base da obsessão pela imagem da modelo, cuja semelhança procurava em todas as vítimas de sexo feminino.

A atmosfera de morte que permeia Obscura pode ser percebida na evocação de outra obra de Manet. Ao ver um buquê de peônias brancas e vermelhas nas mãos do filho, Gabriel Corbel rememora uma pequena natureza-morta do artista, na qual figuravam essas flores, e faz algumas considerações sobre sua maestria no uso dos brancos e sobre o "incrível" aveludado que caracterizava o tratamento das pétalas (Descott, 2010: 149). Como o pintor dedicou várias telas a essa tema, não é fácil determinar qual o quadro da década de 1860 que vem à mente do comerciante de tintas. A partir da referência às dimensões, é possível aventar a hipótese de que a tela evocada seja Haste de peônias e tesoura (1864), em que essa flor, símbolo de luxo e volúpia, remetia à ideia de beleza efêmera e, logo, de vanitas, por estar quase murcha depois do corte sofrido. Se essa hipótese for correta - e ela se aplica também a Ramo de peônias e tesoura (1864) e Vaso de peônias sobre pequeno pedestal (1864) -, é evidente que Descott confronta novamente o leitor com a ideia de morte, acrescentando uma nova peça a seu quebra-cabeça enigmático.

Valendo-se de personagens reais - Victorine, Manet, Blanche ${ }^{14}$ - e de tipos ficcionais, Descott propõe um mergulho não apenas na mente de um

\footnotetext{
${ }^{14}$ Filho de Ésprit, fundador de uma clínica de doenças mentais em Montmartre, transferida depois para a mansão da princesa de Lamballe em Passy, Émile Blanche torna-se seu sucessor. A antiga propriedade da princesa, caracterizada por uma atmosfera de elegância e refinamento, é transformada numa clínica luxuosa, que atendia pacientes famosos como Guy de Maupassant e Gérard de Nerval. Perito de medicina mental do Tribunal do Sena, 0 
criminoso, mas, sobretudo, numa época complexa e contraditória como o final do século XIX. Para compor seu vasto panorama, lança mão de dados como a modernização de Paris, o universo da prostituição e da vida noturna, a realidade das classes inferiores através dos pacientes do doutor Corbel, a medicina legal, os métodos de investigação da polícia, as novas descobertas da psiquiatria, o debate artístico em torno de Manet e sua obra, o estatuto da fotografia, fazendo da descrição minuciosa dos tableaux vivants o elemento determinante de uma narrativa em que a ficção se mescla com fatos reais não para iluminá-los, e sim para convertê-los em interrogações sobre o fenômeno da criação e seus significados mais profundos. Percorrido por essa questão, o romance atinge um momento de condensação quando o doutor Blanche define a criação artística como "a vontade, mesmo que inconsciente, de marcar a própria passagem aqui embaixo". O assassino, portanto, não agiria de maneira gratuita, e sim movido pela vontade de conservar alguns vestígios de sua obra e, logo, de seu nome. Manet teria sido escolhido por ser um provocador, por ter um "renome universal", por ser um "fantasma", no qual o assassino projetava, sem querer, a própria falta de talento (Descott, 2010: 208-209). Mais uma vez emerge a problemática da rivalidade, que Descott trata de maneira instigante, ao negar ao leitor a revelação daquela que deveria ser a "grande obra" de Favre. Seu suicídio, depois de ter sido descoberto e de não ter podido fotografar nem mesmo o primeiro estágio de Olímpia, é o desfecho esperado de uma frustração crescente, que não se contenta com a encenação do quadro do rival, exigindo emoções cada vez mais fortes. Do assassinato como uma das belas-artes, este poderia ser o mote de Obscura, que escapa do romance policial convencional, ao propor ao leitor um enigma que vai além da descoberta do assassino e de suas motivações.

doutor Blanche é autor de diversas obras, entre as quais Des homicides commis par les aliénés (1878) e Quelques considérations sur le traitement moral de la folie (Émile Blanche, s. d.; Émile Blanche - Data BNF - Bibliothèque national de France, s.d.). 


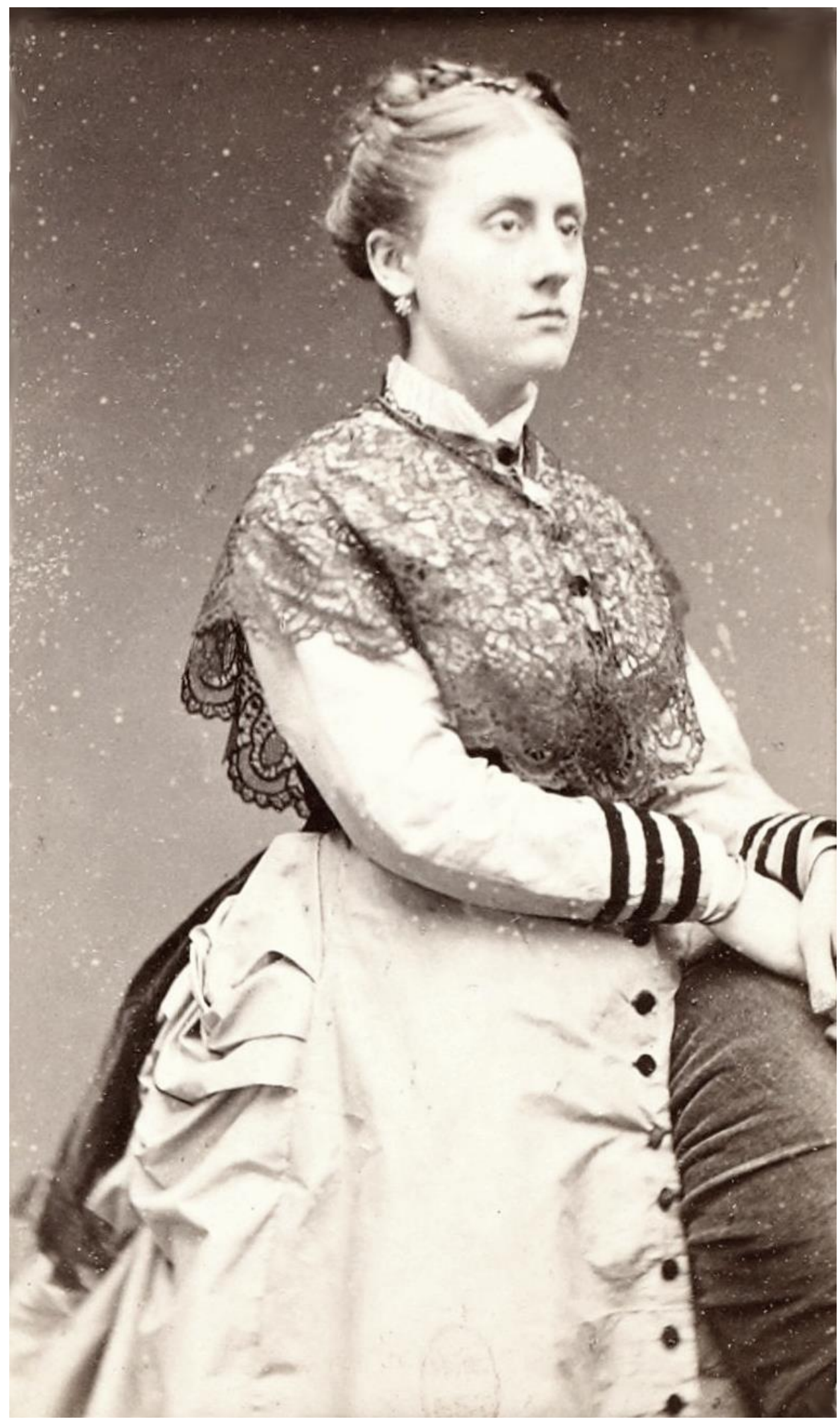

Fig.1. Retrato de Victorine-Louise Meurent. 


\section{Referências}

ALLIEZ, Éric. L'oeil-cerveau: nouvelles histoires de la peinture moderne. Paris: Vrin, 2007.

BLANCHE, Émile Blanche - Data BNF - Bibliothèque nationale de France. Disponível em: <data.bn.fr/13773436/emile_blanche>. Acesso em: 31 maio 2015.

CHEVALIER, Jean; GHEERBRANT, Alain. Dicionário de símbolos; trad. Vera da Costa e Silva et al. Rio de Janeiro: José Olympio, 1991.

DARRAGON, Éric et al.. L'abécédaire de Manet. Paris: Flammarion, 1998.

DESCOTT, Régis. Obscura. Paris: Le Livre de Poche, 2010.

FABRIS, Annateresa. 0 desafio do olhar: fotografia e artes visuais no período das vanguardas históricas, v. I.., 2011.

GREENBERG, Clement. Pintura modernista. In: Ferreira, Glória; Cotrim, Cecília (org.). Clement Greenberg e o debate crítico; trad. Maria Luiza X. de A. Borges. Rio de Janeiro: Funarte/Jorge Zahar, p. 101-110, 1997.

KRIS, Ernst; KURZ, Otto. Lenda, mito e magia na imagem do artista: uma experiência histórica. Lisboa: Editorial Presença, 1998.

LEIRIS, Michel. Le ruban au cou d'Olympia. Paris: Gallimard, 2006.

LETHĖVE, Jacques. Impressionistes et symbolistes devant la presse. Paris: Armand Colin, 1959.

MALLARMÉ, Stéphane. Écrits sur l'art. Paris: GF Flammarion, 2005.

MANET - Kerdonis. Disponível em: <kerdonis.fr/ZMANET01>. Acesso em: 2 jun. 2015.

RUBIN, James H. L'impressionisme. Paris: Phaidon Press, 2008.

SCHARF, Aaron. Arte e fotografia. Torino: Einaudi, 1979.

VENTURI, Lionello. La via dell'impressionismo. Torino: Einaudi, 1970.

VRANCEANU, Alexandra. La conquête du visuel par la langue: la transposition de l'Olympia et du Déjeuner sur l'herbe d'Édouard Manet en romans, 2013. Disponível em: <http://www.fabula.org/colloques/document2002.php>. Acesso em: 25 maio 2015.

ZOLA, Émile. Mon Salon. Manet: écrits sur l'art. Paris: Garnier-Flammarion, 1970. 